\title{
DEVELOPMENT OF THE DELFT INCLINED PLATE (DIP) BIOREACTOR
}

\author{
G. VAN WEERT and P.J. KROES \\ Faculty of Mining and Petroleum Engineering, Dept. of Raw Materials Technology \\ Delft University of Technology, Delft, the Netherlands \\ (Received 23 February 1993; accepted 19 March 1993)
}

\begin{abstract}
Biohydrometallurgy has intrigued many researchers over the last decades, but few processes under controlled plant conditions have resulted. There are several reasons for this, but the important ones are the design limitations on both mass $\left(\mathrm{O}_{2}\right)$ and heat transfer in agitated bioreactors.

The Delf Inclined Plate (DIP) bioreactor is being developed to overcome the current limitations of tank reactors used for bacterial oxidation of sulphide minerals in suspension, namely inefficient power usage $\left(\mathrm{kg} \mathrm{O}_{2} / \mathrm{kWh}\right)$ and the presence of high shear zones, or low rates of oxygen transfer per volume of reactor $\left(\mathrm{kg} \mathrm{O} / 2 / \mathrm{m}^{3} / \mathrm{h}\right)$.
\end{abstract}

The principle of operation of the DIP bioreactor is exceedingly simple and based on the proven floating aerator, used in water and sewage treatments. The latter gives circular surface patterns, each circle created by an individually driven impeller. By "breaking "the circle and using inclined plates instead, the same efficient oxygen transfer is obtained on a linear pattern. The slurry is lifted only $6-8$ feet by one large slurry pumping device, for which the Archimedes screw is recommended. This device is used extensively in the Netherlands for low head pumping of silty water and is characterized by high efficiency and low shear forces. The elevated slurry continuously falls back into the tank via parallel inclined plates as flat, thin sheets, creating many contact lines instead of a few circles and a much higher $\mathrm{O}_{2}$ transfer. Scale up should be linear, at least in one horizontal direction.

A $4 \mathrm{~m}^{3}$ pilot model was designed and installed at the Faculty of Mining and Petroleum Engineering, Delft University of Technology. The unit has been tested with water and has reached $0.25 \mathrm{~kg} \mathrm{O} / \mathrm{m}^{3} / \mathrm{h}$ at approx. $1 \mathrm{~kg} \mathrm{O} \mathrm{O}_{2} / \mathrm{kWh}$. Only pumping limitations have prevented reaching higher rates. The optimum geometric configuration and waterflows are now being established.

Keywords

Biohydrometallurgy, bioreactor, aeration/aerator, oxygen transfer

\section{INTRODUCTION}

The field of complex sulphide ores and their processing offers many opportunities for biohydrometallurgy. From the research work in this field it has become apparent that the action of bacteria can be highly selective with respect to certain minerals. While not a perfect example, the oxidation of pyrite in coal depends on such selectivity. In a mixture of pyrite and arsenopyrite, the latter is preferentially oxidized. Other biohydrometallurgical separations are currently being explored, such as the treatment of cobaltiferous pyrites. 
Selective oxidation, however, requires control of oxidation conditons. This is well recognized in conventional hydrometallurgy, where it is generally related to the redox potential of the solution. Supply of sulphide feed material, i.e. solids which consume oxygen, lowers the redox potential. Supply of the oxidant, which can consist of ferric or cupric ions, chlorine, nitric acid, or in the case of biohydrometallurgy, oxygen in air, raises the redox potential. Process control requires supply and demand to be in equilibrium. Here biohydrometallurgy faces special problems, because control of the supply of oxygen has not been demonstrated in commercial systems.

This paper intends to explore new horizons on oxygen transfer in bioreactors and as such, points the way to process control in the selective treatment of complex ores and concentrates.

\section{Bioreactor Volume Requirements}

It is worthwhile to look at the oxygen transfer requirements of actual biohydrometallurgical systems. Oxygen uptake rates for a continuous pilot plant in the 2:1:1 tank configuration for bio-oxidation of auriferous arsenopyrite have been published 1) as between 140 and $180 \mathrm{~g} \mathrm{O}_{2} / \mathrm{m}^{3} / \mathrm{h}$ or $1800 / 3600=.05$ $\mathrm{g} \mathrm{O}_{2} / \mathrm{m}^{3} / \mathrm{sec}$. With that bioreactor operating at $45 \circ$, the oxygen concentration at saturation is approximately $6 \mathrm{~g} / \mathrm{m}^{3}$. For a proper functioning biosystem the oxygen concentration must be at least $1 \mathrm{~g} / \mathrm{m}^{3}$ solution. The oxygen transfer coefficient, expressed in $\mathrm{sec}^{-1}$, becomes with these conditions approximately:

$0.05=k_{L} a(6-1)$, or $k_{L} a=0.01 \sec ^{-1}$.

The described pilot plant comprises a $32 \mathrm{~m}^{3}$ total tank volume, operating on $15 \mathrm{wt} \%$ solids and, with a seven days residence time, yielding $70-80 \%$ arsenic oxidation and approximately the same percentage gold extraction after subsequent cyanidation. Production capacity of such a system at $1.2 \mathrm{~kg} / \mathrm{l}$ slurry would roughly be

$(32 / 7) \times 0.15 \times 1.2=0.8$ tonne/day of concentrate

The paper [1] reports $500 \mathrm{~kg}$ concentrate per day. The oxygen demand for this concentrate would be approximately $120 \mathrm{~kg} \mathrm{O}$ per day. The dimensional requirements of a DIP bioreactor for this feedstream will be discussed later.

\section{Power Requirements}

The power requirements for a stirred bio-oxidation system are quite complex. First of all, the extent of grinding the ore effects the suspension requirements in the bioreactor. The slurry suspension and air dispersion, resulting in the oxygen transfer, both require energy. Finally, the height of the Stirred Tank BioReactor (STBR) is important, since it effects the energy level of the air supply. As the air becomes injected deeper, i.e. as the STBR becomes taller, the air pressure requirements force a shift from blower to compressor, increasing both capital and operating costs significantly. The biohydrometallurgical profession would be well served by an independent review of energy and cost trade offs between ore grinding, slurry suspension, air compression and stainless steel tank costs as a function of height, similar to what has been done for autoclaves $[2,3]$.

\section{The Delft Inclined Plate (DIP) Bioreactor Concept}

The DIP bioreactor is a linear surface aerator. Instead of creating circular surface patterns, which by necessity leave unused surface, the DIP bioreactor creates linear aeration patterns. It does this by cascading the slurry down inclined parallel plates positioned over the reactor. The sheets of slurry enter the bioreactor with sufficient volume and velocity to entrain air bubbles, thereby creating oxygen transfer by surface aeration. By placing the plates parallel, much more intensive surface aeration should be possible and conceptually a more effective use of the reactor surface is possible. A schematic side view cross-section of the DIP bioreactor prototype is shown in Figure 1. 


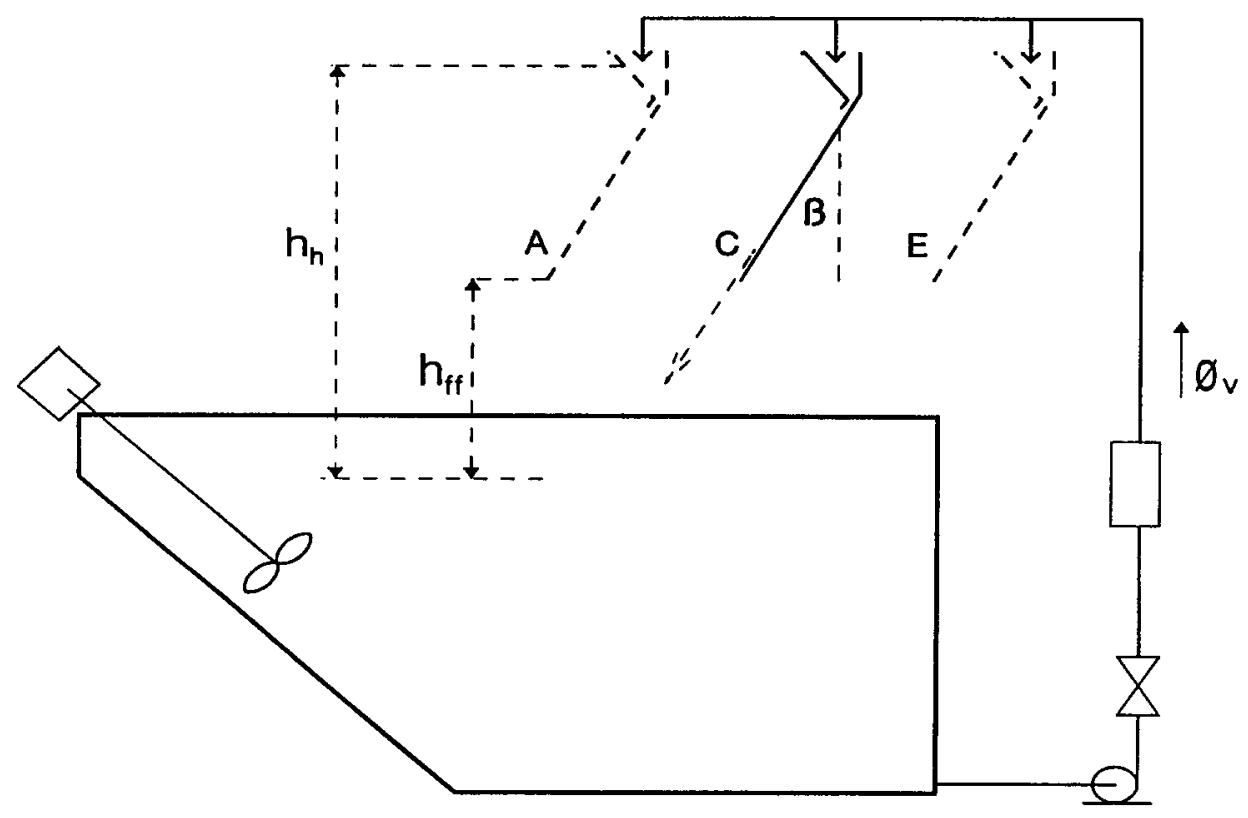

Fig.1 Schematic side view of DIP-bioreactor

One immediate advantage of the DIP concept is the possibility of replacing all individual aerator drives with one common "slurry lifter". The Delft prototype uses an intake manifold over the width of the reactor bottom to feed a single pumping device for all plates.

An inclined agitator is placed in the reactor for suspension, or at least horizontal displacement of the solids. The possibility of sloping the reactor towards the manifold to facilitate movement of solids along the bottom exists. This paper describes work on the water system only, with the inclined agitator in place and operating. Existing CSTR's generally support the agitator on the tank instead of on a separate support structure. This requires a heavier tank construction, costly in stainless steel. The DIP bioreactor can be a clad concrete basin with a wall mounted agitator, either as shown or through the wall. The depth of the DIP bioreactor will never be great, allowing the agitator drives to be mounted above the slurry level.

Since the elevation of the slurry would be small (approximately $2 \mathrm{~m}$ ), pumping devices which are designed for large flow, low head conditions should be considered. The Archimedes screw appears a logical candidate for this duty, since it is also characterized by low tip speed and low shear. Both these properties are important for equipment wear considerations and bacterial husbandry. Jacketing the Archimedes screw housing for cooling purposes could give a self-cleaning heat exchange surface.

Another advantage of surface aeration in this manner is the linear scale up. In theory, the reactor can be lengthened infinitely, perpendicular to the cross-section shown in Figure 1. Extension in the other horizontal directions, i.e. parallel to the cross-section, would depend on the side mounted agitators. Depth would be limited, as with all surface aerator basins.

\section{Prototype}

A prototype DIP reactor was constructed with a volume of $4.14 \mathrm{~m}^{3}$ at $1.50 \mathrm{~m}$ internal water level. The dimensions of the prototype were dictated by the free fall height of the water off the parallel plates, which was set at max. $1.0 \mathrm{~m}$. This was derived from the conventional aerator operation, where the basin contents are generally not lifted more than $1.0 \mathrm{~m}$ above the surface by the aerator mechanism. The width of the reactor was arbitrarily chosen at $1.0 \mathrm{~m}$, as was the length of the plates. The bottom and top lengths of the reactor were 2.0 and $3.5 \mathrm{~m}$, respectively. The prototype DIP bioreactor setup is shown in Figure 2. 


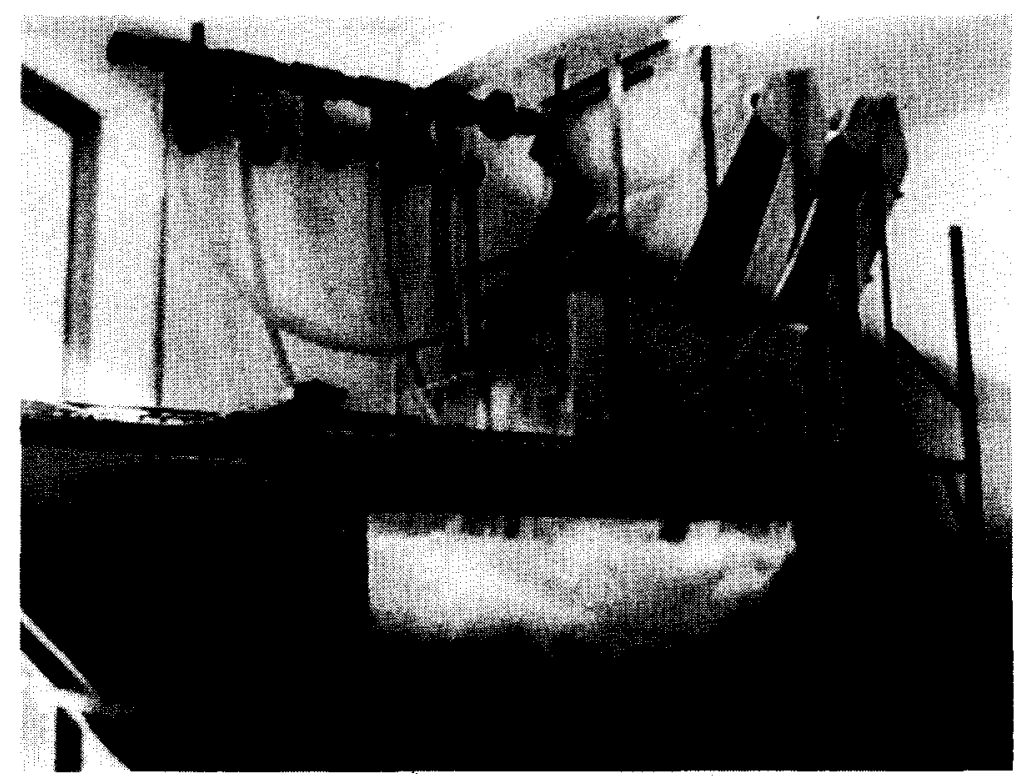

Fig. 2 DIP Bioreactor prototype being tested on water with 3 plates in the C, B and A positions. The cascading sheets of water are difficult to see because of the splash plate mounted in front.

The bubble flow pattern is visible through the window.

Some of the accessory equipment on the prototype is listed below:

- Pump, maximum capacity $75 \mathrm{~m}^{3 / \mathrm{h}}$.

- Magnetic flow meter, for measurement of the volume flow.

- $\quad$ Agitator with hydrofoil impeller (axial flow impeller).

- Watt meter, for measurement of power input to the agitator.

- Membrane probe, equipped with barometric pressure correction for measurement of oxygen concentration $(\mathrm{mg} / 1)$, connected to readout module.

\section{Relevant Measurements}

The two parameters of interest, as discussed earlier, are the volumetric oxygen transfer $(\mathrm{kg} \mathrm{O} / \mathrm{m} 3 / \mathrm{h})$ and the energy efficiency, expressed as $\mathrm{kg} \mathrm{O}_{2}$ transferred per unit of energy $\left(\mathrm{kg} \mathrm{O}_{2} / \mathrm{kWh}\right)$.

The measurement of the oxygen transfer rate was carried out by the standard method of using cobalt catalyzed sodium sulphite oxidation [4], normalized to $10^{\circ} \mathrm{C}$ and $101.3 \mathrm{kPa}$.

The volumetric oxygen transfer rate reported for this test work is a function of reactor depth, since the DIP bioreactor is a surface aerator. Doubling the depth (volume) would half the $\mathrm{kg} \mathrm{O} / \mathrm{m} / \mathrm{h}$. A similar warning must be given for the power usage; the numbers reported relate to the hydraulic pump requirements only and do not take into account the influence, or demands, of the agitator. More work is needed on this subject, and this will be carried out when the testwork is extended from solutions to slurries.

Power requirements of the agitator were directly measured with the Watt meter, but the power requirement for lifting the reactor contents to the distribution trays of the inclined plates was calculated from the relationship $1 \mathrm{~kg} . \mathrm{m}=10 \mathrm{~W}$. sec. It was assumed that an Archimedes screw will be used on a full scale DIP bioreactor with an overall energy utilization of 0.72 (screw efficiency of 0.8 and electric 
drive efficiency of 0.9). The friction of the fluid in the screw was neglected because liquid velocities are low.

\section{TESTWORK}

The following parameters were tested:

$\beta=$ Plate inclination from the vertical: $45^{\circ}$ and $30^{\circ}$.

hff $=$ Height of bottom edge of plate above the water surface: $0.25,0.5$ and $0.75 \mathrm{~m}$ (free fall)

ov $=$ Volume flow of the water discharged from the tank, pumped up and fed over the plates: $25,37.5$ and $75 \mathrm{~m}^{3 / h}$

$\mathrm{PP}=\quad$ Plate positions: A, B, C, D and $\mathrm{E}$ (distances between the positions $\mathrm{A}$ and $\mathrm{B}, \mathrm{B}$ and $\mathrm{C}$, etc. was equal to $0.5 \mathrm{~m}$ ).

The optimum configuration of one plate was determined by carrying out the oxygen transfer measurements for all possible combinations of the defined parameters at the plate positions $\mathrm{A}, \mathrm{C}$ and $\mathrm{E}$. The configuration, which gave the optimum (highest) values for $\mathrm{kg} \mathrm{O}_{2} / \mathrm{m}^{3} / \mathrm{h}$ and $\mathrm{kg} \mathrm{O}_{2} / \mathrm{kWh}$, was used in the tests with multiple plates.

Experiments were also carried out to determine the effect of using two plates. The plate positions $A+B$, $\mathrm{B}+\mathrm{C}, \mathrm{C}+\mathrm{D}$ and $\mathrm{D}+\mathrm{E}$ (distance between the two plates was $0.5 \mathrm{~m}$ ) and the plate positions $\mathrm{A}+\mathrm{C}, \mathrm{B}+\mathrm{D}$ and $C+E$ (distance between the two plates was, therefore, $1 \mathrm{~m}$ ) were tested. A total volume flow of 75 $\mathrm{m}^{3 / h}$ was used (that is $37.5 \mathrm{~m}^{3 / \mathrm{h}}$ per plate), since that was the maximum capacity of the pump available.

Finally experiments were carried out to determine the effect of using three plates at the positions $\mathrm{A}+\mathrm{B}+\mathrm{C}, \mathrm{B}+\mathrm{C}+\mathrm{D}$ and $\mathrm{C}+\mathrm{D}+\mathrm{E}$ (distance between the plates was $0.5 \mathrm{~m}$ ). The optimum configuration determined from the experiments with the single plate was used and a total $\emptyset_{\mathrm{v}}$ amounting $75 \mathrm{~m}^{3} / \mathrm{h}\left(\emptyset_{\mathrm{v}}\right.$ was $25 \mathrm{~m}^{3} / \mathrm{h}$ per plate).

\section{RESULTS}

It became very quickly apparent that position $\mathrm{E}$ gave erratic results because the solution cascade was influenced by the large solution flow into the pump manifold. Results representing only the single plate position $\mathrm{E}$ have been omitted, since on scale up these results would not be significant. The values for $\mathrm{kg}$ $\mathrm{O}_{2} / \mathrm{m}^{3 / h}$ and $\mathrm{kg} \mathrm{O} / \mathrm{kWh}$, which were calculated from the experimental measurements, are given in the tables for the various experimental conditions, as follows:

\section{Angle $\beta$}

For both position $A$ and position $C$ results were slightly more favourable for $\beta=300$ than at 450 . This can be seen by comparing results given in Tables 1 to 4 . The exploratory testwork was, therefore, continued with the plate angle at $30^{\circ}$, with the intention to carry out further optimization at a later date.

\section{Plate Position PP}

Position A also gave slightly better results than position $\mathrm{C}$ for single plate experiments (compare results in Tables 1 and 3, or Tables 2 and 4). It was noticed, however, that the cascade at position $A$ was influenced by the flow pattern of the agitator, i.e. some of the bubbles were drawn into the bottom position of the tank. Further work is needed here also, to define the effect and power draw of the agitator. 
TABLE 1 (plate position $=A, \beta=45^{\circ}$ )

\begin{tabular}{|c|c|c|c|}
\hline $\begin{array}{c}\text { height, hff } \\
(\mathrm{m})\end{array}$ & $\begin{array}{c}\text { volume flow } \emptyset_{\mathrm{v}} \\
\left(\mathrm{m}^{3} / \mathrm{h}\right)\end{array}$ & $\mathrm{kgO}_{2} / \mathrm{m}^{3} / \mathrm{h}$ & $\begin{array}{c}\mathrm{kgO}_{2} / \mathrm{kWh} \\
\text { (hydraulic) }\end{array}$ \\
\hline 0.25 & 25.0 & 0.0367 & 1.17 \\
\hline 0.25 & 37.5 & 0.0837 & 1.80 \\
\hline 0.25 & 75.0 & 0.2319 & 2.48 \\
\hline 0.50 & 25.0 & 0.0568 & 1.55 \\
\hline 0.50 & 37.5 & 0.0919 & 1.67 \\
\hline 0.50 & 75.0 & 0.2475 & 2.25 \\
\hline 0.75 & 25.0 & 0.0672 & 1.59 \\
\hline 0.75 & 37.5 & 0.1038 & 1.65 \\
\hline 0.75 & 75.0 & 0.2654 & 2.10 \\
\hline
\end{tabular}

TABLE 2 (plate position $=A, \beta=30^{\circ}$ )

\begin{tabular}{||c|c|c|c|}
\hline $\begin{array}{c}\text { height hff } \\
(\mathrm{m})\end{array}$ & $\begin{array}{c}\text { volume flow } \Theta_{\mathrm{v}} \\
\left(\mathrm{m}^{3} / \mathrm{h}\right)\end{array}$ & $\mathrm{kgO}_{2} / \mathrm{m}^{3} / \mathrm{h}$ & $\begin{array}{c}\mathrm{kgO}_{2} / \mathrm{kWh} \\
\text { (hydraulic) }\end{array}$ \\
\hline 0.25 & 25.0 & 0.0575 & 1.72 \\
\hline 0.25 & 37.5 & 0.0847 & 1.69 \\
\hline 0.25 & 75.0 & 0.2542 & 2.52 \\
\hline 0.50 & 25.0 & 0.0670 & 1.71 \\
\hline 0.50 & 37.5 & 0.1125 & 1.91 \\
\hline 0.50 & 75.0 & 0.2764 & 2.34 \\
\hline 0.75 & 25.0 & 0.0806 & 1.78 \\
\hline 0.75 & 37.5 & 0.1193 & 1.76 \\
\hline 0.75 & 75.0 & 0.2908 & 2.14 \\
\hline
\end{tabular}

\section{Free-fall Height hff}

Increasing the free fall height clearly has a positive effect, although the $\mathrm{kgO}_{2} / \mathrm{m}^{3} / \mathrm{h}$ does not increase linearly with $h_{f f}$ or the hydraulic head $h_{h}$, especially at the higher flow rate of $75 \mathrm{~m}^{3} / \mathrm{h}$. A free-fall height for obtaining the optimum $\mathrm{kg} \mathrm{O}_{2} / \mathrm{m}^{3} / \mathrm{h}$ was not established (Tables 3 and 4).

The calculated value for the $\mathrm{kg} \mathrm{O}_{2} / \mathrm{kWh}$ transferred also shows an interesting improvement at the 0.75 $\mathrm{m}$ free fall height, for all volume flows tested, indicating a change in the oxygen transfer mechanism at that value for $h f f$. 
TABLE 3 (plate position $=C, \beta=45^{\circ}$ )

\begin{tabular}{|c|c|c|c|}
\hline $\begin{array}{c}\text { height, } \mathrm{hff} \\
(\mathrm{m})\end{array}$ & $\begin{array}{c}\text { volume flow } \emptyset_{\mathrm{v}} \\
\left(\mathrm{m}^{3} / \mathrm{h}\right)\end{array}$ & $\mathrm{kgO}_{2} / \mathrm{m}^{3} / \mathrm{h}$ & $\begin{array}{c}\mathrm{kgO}_{2} / \mathrm{kWh} \\
\text { (hydraulic) }\end{array}$ \\
\hline 0.25 & 25.0 & 0.0343 & 1.10 \\
\hline 0.25 & 37.5 & 0.0510 & 1.10 \\
\hline 0.25 & 75.0 & 0.1252 & 1.34 \\
\hline 0.50 & 25.0 & 0.0446 & 1.22 \\
\hline 0.50 & 37.5 & 0.0643 & 1.17 \\
\hline 0.50 & 75.0 & 0.1729 & 1.57 \\
\hline 0.75 & 25.0 & 0.0625 & 1.48 \\
\hline 0.75 & 37.5 & 0.0954 & 1.51 \\
\hline 0.75 & 75.0 & 0.2254 & 1.78 \\
\hline
\end{tabular}

TABLE 4 (plate position $=C, \beta=30^{\circ}$ )

\begin{tabular}{|c|c|c|c|}
\hline $\begin{array}{c}\text { height, hff } \\
(\mathrm{m})\end{array}$ & $\begin{array}{c}\text { volume flow } \emptyset_{\mathrm{v}} \\
\left(\mathrm{m}^{3} / \mathrm{h}\right)\end{array}$ & $\mathrm{kgO}_{2} / \mathrm{m}^{3} / \mathrm{h}$ & $\begin{array}{c}\mathrm{kgO}_{2} / \mathrm{kWh} \\
\text { (hydraulic) }\end{array}$ \\
\hline 0.25 & 25.0 & 0.0396 & 1.18 \\
\hline 0.25 & 37.5 & 0.0646 & 1.29 \\
\hline 0.25 & 75.0 & 0.1664 & 1.66 \\
\hline 0.50 & 25.0 & 0.0513 & 1.31 \\
\hline 0.50 & 37.5 & 0.0792 & 1.34 \\
\hline 0.50 & 75.0 & 0.1840 & 1.56 \\
\hline 0.75 & 25.0 & 0.0642 & 1.42 \\
\hline 0.75 & 37.5 & 0.1005 & 1.48 \\
\hline 0.75 & 75.0 & 0.2584 & 1.90 \\
\hline
\end{tabular}

\section{Volume Flow Øv}

Three flows were tested: $25,37.5$ and $75 \mathrm{~m}^{3} / \mathrm{h}$. This allowed for later comparison of standardized flows over multiple plates. The $\mathrm{kg} \mathrm{O} / \mathrm{m}^{3} / \mathrm{h}$ transferred was found to be at least linear with flow, i.e. tripling the cascading flow also tripled the volumetric oxygen transfer at all three free fall heights tested (Tables 3 and 4). Pump capacity limitations prevented experimentation at higher flow rates. The calculated $\mathrm{kgO}_{2} / \mathrm{kWh}$ also suggests that further experimentation in this direction would be useful. 


\section{Multiple Plates}

Tables 5 and 6 list the experiments with multiple plates, all $1 \mathrm{~m}$ long. Use of two plates, each cascading $37.5 \mathrm{~m}^{3} / \mathrm{h}$ solution gives a lower oxygen transfer and less efficient power consumption than cascading 75 $\mathrm{m}^{3 / h}$ solutions over 1 plate. The position of the plates appeared to be of little influence.

Splitting the $75 \mathrm{~m}^{3} / \mathrm{h}$ equally over three plates (Table 8) gave even less attractive results than the single flow-single plate option, and did not match tripling the $0.0642 \mathrm{~kg} \mathrm{O}_{2} / \mathrm{m}^{3} / \mathrm{h}$ for $25 \mathrm{~m}^{3} / \mathrm{h}$ for position C. Possibly there is some negative interference between closely placed plates.

TABLE $5\left(\mathrm{~h}=0.75 \mathrm{~m}, \sigma=75 \mathrm{~m}^{3} / \mathrm{h}, \beta=30^{\circ}, 2\right.$ plates)

\begin{tabular}{|c|c|c||}
\hline $\begin{array}{c}\text { Plate: } \\
\text { Positions }\end{array}$ & $\mathrm{kgO}_{2} / \mathrm{m}^{3} / \mathrm{h}$ & $\begin{array}{c}\mathrm{kgO} / \mathrm{kWh} \\
\text { (hydraulic) }\end{array}$ \\
\hline $\mathrm{D}+\mathrm{E}$ & 0.2154 & 1.59 \\
\hline $\mathrm{C}+\mathrm{D}$ & 0.1990 & 1.46 \\
\hline $\mathrm{B}+\mathrm{C}$ & 0.1911 & 1.40 \\
\hline $\mathrm{A}+\mathrm{B}$ & 0.2035 & 1.50 \\
\hline $\mathrm{C}+\mathrm{E}$ & 0.1942 & 1.43 \\
\hline $\mathrm{B}+\mathrm{D}$ & 0.2184 & 1.61 \\
\hline $\mathrm{A}+\mathrm{C}$ & 0.1984 & 1.46 \\
\hline
\end{tabular}

TABLE $6\left(\mathrm{~h}=0.75 \mathrm{~m}, \phi=75 \mathrm{~m}^{3} / \mathrm{h}, \beta=30^{\circ}, 3\right.$ plates $)$

\begin{tabular}{|c|c|c|}
\hline $\begin{array}{c}\text { Plate } \\
\text { Positions: }\end{array}$ & $\mathrm{kgO}_{2} / \mathrm{m}^{3} / \mathrm{h}$ & $\begin{array}{l}\mathrm{kgO}_{2} / \mathrm{kWh} \\
\text { (hydraulic) }\end{array}$ \\
\hline $\mathrm{A}+\mathrm{B}+\mathrm{C}$ & 0.1606 & 1.18 \\
\hline $\mathrm{B}+\mathrm{C}+\mathrm{D}$ & 0.1768 & 1.30 \\
\hline $\mathrm{C}+\mathrm{D}+\mathrm{E}$ & 0.1907 & 1.40 \\
\hline
\end{tabular}

\section{DIP bioreactor dimensional requirements}

Retuming to the earlier mentioned $32 \mathrm{~m}^{3}$ biohydrometallurgical system, requiring transfer of $120 \mathrm{~kg} \mathrm{O}$ per day, the required plate size of four similar DIP bioreactors can be estimated from these early results as follows.

At a solution flow of $75 \mathrm{~m}^{3} / \mathrm{h}$ approximately $0.75 \mathrm{~kg} \mathrm{O} / \mathrm{h}$ is transferred in the $4 \mathrm{~m}^{3}$ pilot unit, or $10 \mathrm{~g}$ oxygen for each $\mathrm{m}^{3}$ solution flowing over the plate(s). A $120 \mathrm{~kg} \mathrm{O}$ per day, or $5000 \mathrm{~g} \mathrm{O}_{2}$ per hour demand, would require $500 \mathrm{~m} 3 / \mathrm{h}$ slurry flowing over one plate, as described, with approximately (500/75) $\times 1=6.0 \mathrm{~m}$ total width or $1.5 \mathrm{~m}$ width per bioreactor in the $2: 1: 1$ configuration. This assumes no further improvements in performance with higher flow rates over the plate(s). The Archimedes screw would be approximately $1 \mathrm{~m}$ diameter and turn at $60 \mathrm{rpm}$ consuming $3 \mathrm{~kW}$. The DIP bioreactors would be $3 \times 1.5$ $x 1.5 \mathrm{~m}$ each, which would be comparable in volume to the pilot plant described in [1]. 


\section{DISCUSSION AND CONCLUSION}

The DIP bioreactor appears capable of yielding high volumetric oxygen transfer rates, measured at approximately $0.25 \mathrm{~kg} \mathrm{O}_{2} / \mathrm{m}^{3} /$ hour for the highest flowrate available for the pilot unit over a single plate in the centre position. As such, the concept appears successful.

The concept of using the reactor surface more intensively by exploring multiple parallel plates is not totally valid and needs further work. The optimum cascading height, plate angle, cascading volume per plate and plate spacing still need to be determined and work is continuing on these subjects.

In summary, the advantages originally foreseen for the DIP bioreactor remain, i.e. high oxygen transfer at low power levels with no high shear zones in the reactor or its pumping loop. The possibility of installing self-cleaning heat transfer surfaces around the Archimedes screw or under the inclined plates offers possibilities to solve the problem of heat transfer as well. Linear scale-up appears feasible. Substantial reductions from presently proposed bioreactor volume and energy consumption appear very feasible opening the door to controlling the oxygen supply to biohydrometallurgical reactors and, thereby, controlling the selectivity of the mineral oxidation. Work is continuing.

\section{REFERENCES}

1. Spencer, P.A., Budden, J.R. \& Barett, J., Pilot plant bio-oxidation of gold-bearing arseno-pyrite concentrates, Trans. Inst. Min. Metall. 100, C21-C24 (Jan-April 1991).

2. Mason, P.G., Energy requirements for the pressure oxidation of gold bearing sulphides, Journal of Metals, 42, 15-18 (Sept. 1990).

3. Conway, M.H. \& Gale, C., Sulphur's impact on the size of pressure oxidation autoclaves, Journal of Metals, 42, 19-22 (Sept. 1990).

4. Baillod, Robert C. \& Paulson, W., Proposed standard for measurement of oxygen transfer in clean water, Aeration systems, 2-6 (1982). 